\title{
The effect of oak tannin (Quercus robur) and hops (Humulus Iupulus) on dietary nitrogen efficiency, methane emission, and milk fatty acid composition of dairy cows fed a low-protein diet including linseed
}

\author{
M. Focant, ${ }^{1}$ E. Froidmont, ${ }^{2 *}$ Q. Archambeau, ${ }^{1}$ Q. C. Dang Van, ${ }^{1}$ and $Y$. Larondelle ${ }^{1}$ \\ ${ }^{1}$ Louvain Institute of Biomolecular Science and Technology, Université Catholique de Louvain, Croix du Sud, 2, L7.05.08, 1348 Louvain la Neuve, \\ Belgium \\ ${ }^{2}$ Animal Nutrition and Sustainability Unit, Walloon Agricultural Research Center, Gembloux, 5030 Belgium
}

\section{ABSTRACT}

The objective of this study was to test the effects of inclusion of hop pellets (HP) and oak tannin extracts (OT) alone or in combination on $\mathrm{N}$ efficiency, methane $\left(\mathrm{CH}_{4}\right)$ emission, and milk production and composition in 2 experiments with dairy cows fed low- $\mathrm{N}$ rations supplemented with linseed. In both experiments, 6 lactating Holstein cows were assigned to 3 dietary treatments in a $3 \times 3$ duplicated Latin square design (21-d periods). Cows were fed a total mixed ration at a restricted level to meet their nutrient requirements. In experiment 1, $169 \mathrm{~g}$ dry matter (DM) of OT or $56 \mathrm{~g}$ DM of HP was included separately in the control diet (C1). In experiment 2, the additives were included together (OT-HP) in the control diet (C2) similar to C1. Diet $\mathrm{C} 2$ was compared with a control without linseed $(\mathrm{C} 0)$. In experiment 1 , the supplementation of the control diet with OT decreased urinary $\mathrm{N}$ excretion by $12 \%$. In experiment 2, the combination of OT and HP decreased urinary $\mathrm{N}$ by $7 \%$. Oak tannin extracts and $\mathrm{HP}$ alone or in combination did not influence the daily enteric $\mathrm{CH}_{4}$ production of cows. Cows fed diet $\mathrm{C} 0$ produced $17 \%$ more enteric $\mathrm{CH}_{4}$ daily than those fed diet $\mathrm{C} 2$. Intake of diet $\mathrm{C} 2$, which contained $6.7 \%$ extruded linseed on a DM basis (experiment 2), decreased the sum of 6:0 to 14:0 fatty acids $(-16 \%)$ and palmitic acid $(-26 \%)$ and increased the stearic acid $(+50 \%)$, oleic acid $(+36 \%)$, vaccenic acid (trans-11 18:1; +285\%), rumenic acid (cis-9,trans-11 18:2; +235\%), and $\alpha$-linolenic acid $(+100 \%)$ in milk fat. The supplementation of diet C2 with the OT-HP mixture further improved the milk's fatty acid composition. Intake of the OT alone increased a-linolenic acid by $17.7 \%$ (experiment 1 ). The results

Received July 31, 2018.

Accepted October 16, 2018.

*Corresponding author: e.froidmont@cra.wallonie.be of this study show that at the economically acceptable dose we tested, hops had no effect on urinary N excretion, $\mathrm{CH}_{4}$ emission, milk production, and milk composition. By contrast, supplementation of diets with oak tannin extract can be considered for reducing urinary $\mathrm{N}$ excretion. The combination of oak tannin and hops had no more effect than oak tannin alone except on the milk fatty acid profile, which was favorably influenced from a nutritional point of view.

Key words: hops, oak tannin, nitrogen efficiency, methane, milk fatty acids

\section{INTRODUCTION}

Dairy cows substantially contribute to emissions of greenhouse gases, mainly through methane $\left(\mathrm{CH}_{4}\right)$ from ruminal fermentation (Gerber et al., 2013). Moreover, in European dairy herds, breeders often distribute rations in which the protein content is higher than the real needs of the animals. This overfeeding increases ammonia $\left(\mathrm{NH}_{3}\right)$ outflow from the rumen. Ammonia is then converted to urea in the liver and excreted mainly in urine (Ulyatt et al., 1975). During manure storage, urea is quickly hydrolyzed to $\mathrm{NH}_{3}$. This can later be nitrified to nitrate, which is in turn partly converted to nitrous oxide $\left(\mathrm{N}_{2} \mathrm{O}\right)$ during denitrification (Eckard et al., 2010). With a very high global warming potential, $\mathrm{N}_{2} \mathrm{O}$ is the third largest greenhouse gas (Dijkstra et al., 2013).

Among the dietary strategies already proposed to mitigate enteric $\mathrm{CH}_{4}$, linseed supplementation seems to be one of the most effective (Martin et al., 2010; Benchaar et al., 2015). Furthermore, linseed improves the nutritional value of milk fat by decreasing milk SFA content and increasing CLA and $\alpha$-linolenic acid (ALA; Focant et al., 1998; Chilliard et al., 2009). In cows in mid lactation, a significant decrease of urinary $\mathrm{N}$ excretion can be achieved by reducing dietary CP from 17 to $19 \%$ to 14 to $16 \%$ of DM without effect (Leonardi et al., 2003; Colmenero and Broderick, 2006; 
Mutsvangwa et al., 2016) or with very small effects (Broderick, 2003) on milk and protein yield, resulting in an overall improvement in milk $\mathrm{N}$ efficiency (Castillo et al., 2000; Frank et al., 2002).

Selected feed additives may also improve feed efficiency in dairy cattle. The potential of tannins (hydrolyzable and condensed) to increase the digestive utilization of dietary protein for ruminants is associated with their ability to bind proteins in the rumen, preventing their excessive microbial degradation. Tannin-protein complexes are dissociated by the acidic $\mathrm{pH}$ of the abomasum or in the alkaline conditions of the small intestine, releasing protein for digestion and absorption (Barry and McNabb, 1999). Some tannins added to ruminant diets have also been shown to reduce ruminal $\mathrm{CH}_{4}$ production without adversely affecting the efficiency of ruminal fermentation (Bhatta et al., 2009; Patra and Saxena, 2011; Jayanegara et al., 2012). Among the different sources of tannin, oak extracts, which are rich in hydrolyzable tannins, are a new potential feed additive.

Hop flowers (Humulus lupulus L.), which are added to beer as a preservative, are also a potential feed additive to reduce rumen $\mathrm{CH}_{4}$ emission and protein degradation. The antimicrobial components of hops, including humulone, lupulone (typically called $\alpha$ - and $\beta$-acids, respectively), and their isomers, inhibit the lactic acid bacteria that spoil beer (Sakamoto and Konings, 2003). Flythe (2009) showed that hyper- $\mathrm{NH}_{3}$-producing bacteria species present in the rumen are sensitive to the antimicrobial components of hops. Hops used in in vitro experiments decreased $\mathrm{DM}$ and $\mathrm{CP}$ rumen degradability without affecting DM and CP digestibility (Lavrenčič et al., 2014). Inclusion of hops at levels between 400 and $800 \mathrm{mg} / \mathrm{L}$ of culture fluid in in vitro ruminal incubations reduced $\mathrm{CH}_{4}$ production and the acetate:propionate ratio (Narvaez et al., 2011, 2013; Dang Van et al., 2018). Hops thus appear to be another promising natural feed additive for decreasing ruminal $\mathrm{CH}_{4}$ production.

From in vitro experiments, Dang Van et al. (2018) concluded that when used in combination, hop pellets and oak extracts may complement one another to decrease ruminal $\mathrm{CH}_{4}$ production and $\mathrm{NH}_{3}$ outflow in ruminants. Considering the scarcity of published data evaluating in vivo the potential of hops and oak tannins and the absence of information on the combined effects of these 2 types of feed additives, we designed the present study to test the effects of inclusion of hop pellets and oak extracts alone or in combination on $\mathrm{N}$ efficiency, $\mathrm{CH}_{4}$ emission, and milk production and composition in 2 experiments with dairy cows fed low$\mathrm{N}$ rations supplemented with linseed.

\section{MATERIALS AND METHODS}

The handling of the 12 dairy cows used in the 2 experiments of this study was in accordance with the recommendations on care and use of the Comité d'Éthique en Expérimentation Animale (registration no. 1404 and 1529).

\section{Experimental Design}

In both experiments, 6 lactating Holstein cows were blocked according to their milk yield, DIM, and parity. They were assigned to 3 dietary treatments in a $3 \times 3$ duplicated Latin square design. Each experimental period lasted $21 \mathrm{~d}(14 \mathrm{~d}$ of treatment adaptation and $7 \mathrm{~d}$ of data collection and sampling). Cows were housed in individual tiestalls, with the floor covered with rubber mats. Cows had free access to water. Experimental diets were formulated and fed at a restricted level to meet the cows' nutrient requirements (CVB, 2016) based on their recorded milk production just before the start of the experiment. The TMR were fed at 0800 and 1630 $\mathrm{h}$ in equal amounts. Milking took place twice daily at 0730 and $1600 \mathrm{~h}$.

\section{Cows and Diets}

Experiment 1. At the beginning of the experiment the cows averaged (mean \pm SD) $2 \pm 1.5$ lactations, $154 \pm 56.9$ DIM, and $612 \pm 56 \mathrm{~kg}$ of BW and yielded $29.1 \pm 2.54 \mathrm{~kg}$ of milk/d. The main ingredients of the control diet (C1; Table 1) were corn silage, grass silage, dehydrated alfalfa, rapeseed meal, rolled barley, and sugar beet pulp. Nutex 68 (Dumoulin, Seilles, Belgium) was used as the source of extruded linseed. Vitamin E $(8 \mathrm{~g} / \mathrm{d})$ was added to prevent milk fat oxidation (Focant et al., 1998). The 2 other diets were similar to $\mathrm{C} 1$ but were supplemented with $169 \mathrm{~g}$ DM of oak tannin extract (OT; heartwood of Quercus robur and Quercus petrea; Oxylent, Ghislenghien, Belgium; $61 \%$ of total polyphenols in DM according to the manufacturer's information) or $56 \mathrm{~g}$ DM of hop pellets (HP; Humulus lupulus, female inflorescence; Yakima Chief SA, Louvain-la-Neuve, Belgium) of the Palisade variety, which contains an average of $8.25 \%$ of $\alpha$-acids and $6.75 \%$ of $\beta$-acids in the DM according to the manufacturer's information. The quantities of HP and OT added to the ration were determined on the basis of the minimum active doses in vitro (Dangvan et al., 2018) and the economic cost considered to be bearable for the farmers.

Experiment 2. At the beginning of the experiment, the cows averaged (mean \pm SD) $2 \pm 1.5$ lactations, $80 \pm 18.7 \mathrm{DIM}$, and $592 \pm 58 \mathrm{~kg}$ of $\mathrm{BW}$ and yielded 
Table 2. Ingredients and chemical composition of the experimental total mixed diets without extruded linseed $(\mathrm{C} 0)$, with extruded linseed $(\mathrm{C} 2)$, or with extruded linseed and oak tannin and hop pellet (OT-HP) supplementation (experiment 2)

\begin{tabular}{|c|c|c|c|}
\hline \multirow[b]{2}{*}{ Item } & \multicolumn{3}{|c|}{ Diet } \\
\hline & $\mathrm{C} 0$ & $\mathrm{C} 2$ & OT-HP \\
\hline \multicolumn{4}{|l|}{ Ingredient, $\%$ of $\mathrm{DM}$} \\
\hline Corn silage & 36.80 & 36.13 & 35.71 \\
\hline Prewilted grass silage & 21.79 & 21.47 & 21.22 \\
\hline Dehydrated alfalfa $^{1}$ & 6.78 & 6.81 & 6.73 \\
\hline Rolled barley & 0 & 10.99 & 10.87 \\
\hline Rapeseed meal & 11.14 & 9.95 & 9.83 \\
\hline Nutex $68^{2}$ & 0 & 9.95 & 9.83 \\
\hline Beet pulp & 21.31 & 2.09 & 2.07 \\
\hline Beet molasses & 1.45 & 1.57 & 1.55 \\
\hline Chalk & 0 & 0.26 & 0.26 \\
\hline Salt & 0.24 & 0.26 & 0.26 \\
\hline Mineral and vitamin $\operatorname{mix}^{3}$ & 0.48 & 0.52 & 0.52 \\
\hline Oak tannin & 0 & 0 & 0.87 \\
\hline Hop pellets & 0 & 0 & 0.29 \\
\hline \multicolumn{4}{|c|}{ Chemical composition ( $\mathrm{g} / \mathrm{kg}$ of DM unless noted) } \\
\hline $\mathrm{OM}$ & 928 & 935 & 935 \\
\hline $\mathrm{CP}$ & 130 & 141 & 141 \\
\hline $\mathrm{NDF}$ & 430 & 374 & 374 \\
\hline Starch & 125 & 202 & 202 \\
\hline Fat & 2.5 & 5.1 & 5.1 \\
\hline $\mathrm{DVE}^{4}$ & 75.5 & 79.6 & 79.6 \\
\hline $\mathrm{OEB}^{5}$ & -2.0 & 4.3 & 4.3 \\
\hline $\mathrm{NE}_{\mathrm{L}}{ }^{6}{ }^{6} \mathrm{Mcal} / \mathrm{kg}$ of DM & 1.52 & 1.66 & 1.66 \\
\hline \multicolumn{4}{|l|}{ Fatty acids, $\mathrm{g} / \mathrm{kg}$ of DM } \\
\hline 14:0 & 0.1 & 0.1 & 0.1 \\
\hline 16:0 & 2.0 & 4.1 & 4.0 \\
\hline $16: 1$ & 0.1 & 0.1 & 0.1 \\
\hline 18:0 & 0.3 & 1.4 & 1.4 \\
\hline cis-9 18:1 & 2.9 & 7.9 & 7.8 \\
\hline cis-9,cis-12 18:2 & 4.9 & 9.9 & 9.8 \\
\hline cis-9,cis-12,cis-15 18:3 & 1.9 & 17.3 & 17.1 \\
\hline
\end{tabular}

${ }^{1}$ Long-strand dehydrated alfalfa range in bales (Désialis, Paris, France).

${ }^{2}$ Extruded concentrate comprising $67.7 \%$ linseed, $20 \%$ wheat shorts, $10.4 \%$ wheat, $1.8 \%$ butylated hydroxytoluene, and $0.1 \%$ salt (Dumoulin, Seilles, Belgium).

${ }^{3}$ Declared contents: $15 \% \mathrm{Ca}, 5 \% \mathrm{Mg}, 5 \% \mathrm{P}, 1 \% \mathrm{Na}, 6,000 \mathrm{mg}$ of $\mathrm{Zn} / \mathrm{kg}, 3,300 \mathrm{mg}$ of $\mathrm{Mn} / \mathrm{kg}, 1,250 \mathrm{mg}$ of $\mathrm{Cu} /$ $\mathrm{kg}, 100 \mathrm{mg}$ of I/ $\mathrm{kg}, 50 \mathrm{mg}$ of Co/kg, $20 \mathrm{mg}$ of Se/kg, 1,200,000 IU of vitamin A/ $/ \mathrm{kg}, 200,000 \mathrm{IU}$ of vitamin $\mathrm{D}_{3} /$ $\mathrm{kg}$, and 2,000 IU of vitamin E/kg (Célémin, Dumoulin, Belgium).

${ }^{4}$ True proteins digested in the intestine (van Duinkerken et al., 2011).

${ }^{5}$ Rumen-degradable protein balance (van Duinkerken et al., 2011).

${ }^{6}$ Net energy for lactation calculated with the feed unit lactation (VEM) system (Van Es, 1975).

In experiment $1, \mathrm{CH}_{4}$ production was estimated from the analysis of the mid-infrared spectra of milk (Vanlierde et al., 2016). In experiment $2, \mathrm{CH}_{4}$ production was determined by the sulfur hexafluoride $\left(\mathrm{SF}_{6}\right)$ tracer technique (Johnson et al., 1994) as described by Martin et al. (2008).

The fatty acid profiles in feedstuffs and in milk samples were determined by GC. Lipids in feedstuffs were extracted using the method of Folch modified by Christie (1982), and the method described by Hara and Radin (1978) was used to extract lipids from milk. Fatty acid methylation and further separation and quantification of the methyl esters were performed as described by Dang Van et al. (2011).

\section{Statistical Analysis}

The statistical analyses were the same for both experiments. Data for intake, digestibility, milk production, $\mathrm{N}$ excretion, $\mathrm{CH}_{4}$ production, and fatty acid profiles were summarized for each cow by period. All data from experiments were reported as least squares means \pm standard error of the mean and were analyzed as a replicated Latin square using the MIXED procedure of SAS (version 9.3; SAS Institute Inc., Cary, NC). The statistical model included period, cow, diet, and random error. Period and diet were fixed effects, whereas cow was the random effect. Overall differences between treatment means were considered to be significant 
Table 3. Intake and fecal apparent digestibility of nutriments in lactating cows fed a total mixed diet (C1) with hop pellet (HP) or oak tannin (OT) supplementation (experiment 1)

\begin{tabular}{|c|c|c|c|c|c|}
\hline \multirow[b]{2}{*}{ Item } & \multicolumn{3}{|c|}{ Diet } & \multirow[b]{2}{*}{ SEM } & \multirow[b]{2}{*}{$P$-value } \\
\hline & $\mathrm{C} 1$ & HP & OT & & \\
\hline \multicolumn{6}{|c|}{ Intake, $\mathrm{kg} / \mathrm{d}$} \\
\hline DM & 18.82 & 18.89 & 18.84 & 0.21 & 0.47 \\
\hline $\mathrm{OM}$ & 17.44 & 17.49 & 17.44 & 0.19 & 0.53 \\
\hline $\mathrm{CP}$ & 2.49 & 2.49 & 2.49 & 0.03 & 0.69 \\
\hline \multicolumn{6}{|c|}{ Apparent digestibility, \% } \\
\hline DM & 67.9 & 68.3 & 67.5 & 0.75 & 0.38 \\
\hline $\mathrm{OM}$ & 70.8 & 71.1 & 70.3 & 0.79 & 0.28 \\
\hline $\mathrm{CP}$ & $61.3^{\mathrm{a}}$ & $61.7^{\mathrm{a}}$ & $60.3^{\mathrm{b}}$ & 1.12 & $<0.01$ \\
\hline
\end{tabular}

${ }^{\mathrm{a}, \mathrm{b}}$ Means within a row with no common superscript differ $(P<0.05)$.

when $P<0.05$. When a significant treatment effect was observed, the Tukey option was used to compare pairs of means.

\section{RESULTS}

\section{Experiment 1}

Feed Intake and Apparent Digestibility. As already explained, the diets were distributed in restricted amounts (Table 1) according to the requirements of the cows. As a consequence, refusals were scarce $(<2 \%$ of distributed feeds) and intake of $\mathrm{DM}, \mathrm{OM}$, and $\mathrm{CP}$ was similar among cows and treatments (Table 3). Table 3 shows fecal apparent digestibility of DM, OM, and CP. Digestibility of DM and OM did not differ significantly between treatments $(P>0.05)$. However, the addition of OT to the diet significantly decreased CP digestibility ( $60.3 \%$ vs. $61.3 \%$ for control diet). Hop pellets did not influence the digestibility of the diet.

Milk Production and Milk Composition. Table 4 presents the results of the effects of HP or OT supplementation on milk production. Addition of HP and OT to control diet $\mathrm{C} 1$ did not affect any of the param- eters measured. Milk yields and milk composition were similar for all rations. The treatments did not influence MUN, but urea content was very low in milk, probably due to the low protein content in the diets.

$N$ Balance. Table 5 presents the data for $\mathrm{N}$ outputs and $\mathrm{N}$ balance. Nitrogen intake, total $\mathrm{N}$ excretion, and milk N production were similar for all diets. Supplementation of the diet with OT increased fecal N excretion $(P=0.02)$ and decreased $\mathrm{N}$ excreted in urine $(P=$ 0.01 ) by $12 \%$. The effect of HP on urinary $\mathrm{N}$ excretion was not significant. The additives did not affect daily total $\mathrm{N}$ excretion. The efficiency of $\mathrm{N}$ utilization for milk production was about $34 \%$ of $\mathrm{N}$ intake and was not affected by OT or HP supplementation.

Estimation of Enteric $\mathrm{CH}_{4}$ Production. On the basis of mid infrared spectra of milk (Vanlierde et al., 2016), supplementation of the control diet with HP or OT did not influence the cows' daily enteric $\mathrm{CH}_{4}$ production expressed in grams per day, grams per kilogram of DMI, grams per kilogram of milk, or grams per kilogram of ECM (Table 6).

Milk Fatty Acid Composition. The fatty acid profile of the milk that the cows produced corresponded to that produced by cows consuming extruded linseeds.

Table 4. Milk production and milk composition of lactating cows fed a total mixed diet (C1) with hop pellet (HP) or oak tannin (OT) supplementation (experiment 1)

\begin{tabular}{|c|c|c|c|c|c|}
\hline \multirow[b]{2}{*}{ Item } & \multicolumn{3}{|c|}{ Diet } & \multirow[b]{2}{*}{ SEM } & \multirow[b]{2}{*}{$P$-value } \\
\hline & $\mathrm{C} 1$ & $\mathrm{HP}$ & OT & & \\
\hline \multicolumn{6}{|l|}{ Production, kg/d } \\
\hline Milk & 25.9 & 26.5 & 26.5 & 1.08 & 0.62 \\
\hline $\mathrm{ECM}^{1}$ & 26.1 & 26.4 & 26.5 & 1.43 & 0.68 \\
\hline \multicolumn{6}{|l|}{ Composition } \\
\hline Fat, \% & 4.04 & 4.02 & 4.01 & 0.20 & 0.97 \\
\hline Protein, \% & 3.26 & 3.22 & 3.26 & 0.08 & 0.57 \\
\hline MUN, mg/dL & 4.28 & 4.24 & 4.08 & 0.93 & 0.87 \\
\hline \multicolumn{6}{|l|}{ Yield, g/d } \\
\hline Fat & 1,056 & 1,065 & 1,072 & 69 & 0.82 \\
\hline Protein & 844 & 851 & 862 & 31 & 0.75 \\
\hline
\end{tabular}

${ }^{1} \mathrm{ECM}(\mathrm{kg})=[0.337+(0.116 \times \%$ fat $)+(0.06 \times \%$ protein $)] \times$ production $(\mathrm{kg})(\mathrm{CVB}, 2008)$. 
Table 5. Nitrogen balance in lactating cows fed a total mixed diet (C1) with hop pellet (HP) or oak tannin (OT) supplementation (experiment 1)

\begin{tabular}{|c|c|c|c|c|c|}
\hline \multirow[b]{2}{*}{ Item } & \multicolumn{3}{|c|}{ Diet } & \multirow[b]{2}{*}{ SEM } & \multirow[b]{2}{*}{$P$-value } \\
\hline & $\mathrm{C} 1$ & $\mathrm{HP}$ & OT & & \\
\hline $\mathrm{N}$ intake, $\mathrm{g} / \mathrm{d}$ & 394 & 395 & 395 & 4.1 & 0.69 \\
\hline \\
\hline $\mathrm{g} / \mathrm{d}$ & $152^{\mathrm{b}}$ & $151^{\mathrm{b}}$ & $157^{\mathrm{a}}$ & 3.8 & 0.02 \\
\hline & 38.6 & 38.2 & 39.7 & 1.0 & 0.02 \\
\hline \multicolumn{6}{|l|}{ Urinary N } \\
\hline $\mathrm{g} / \mathrm{d}$ & $107^{\mathrm{a}}$ & $101^{\mathrm{ab}}$ & $94^{\mathrm{b}}$ & 7.5 & 0.01 \\
\hline$\%$ of $\mathrm{N}$ intake & 27.2 & 25.6 & 23.8 & 1.8 & 0.01 \\
\hline \multicolumn{6}{|c|}{ Total N excretion } \\
\hline $\mathrm{g} / \mathrm{d}$ & 259 & 252 & 251 & 4.8 & 0.09 \\
\hline$\%$ of $\mathrm{N}$ intake & 65.7 & 63.8 & 63.5 & 1.2 & 0.09 \\
\hline \multicolumn{6}{|l|}{ Milk N } \\
\hline $\mathrm{g} / \mathrm{d}$ & 134 & 135 & 136 & 4.7 & 0.98 \\
\hline$\%$ of $\mathrm{N}$ intake & 34.0 & 34.2 & 34.4 & 1.2 & 0.98 \\
\hline
\end{tabular}

${ }^{\mathrm{a}, \mathrm{b}}$ Means within a row with no common superscript differ $(P<0.05)$.

The proportion of ALA and cis-9,trans-11 18:2 CLA exceeded $1 \%$ of total fatty acids, and that of UFA was above $30 \%$. Hops did not significantly influence milk fatty acid levels. However, ALA was increased by $17.7 \%$ when cows consumed OT $(P=0.04)$. Consequently, the linoleic acid (LA):ALA ratio was decreased by $8.8 \%$ (Table $7 ; P=0.02$ ).

\section{Experiment 2}

Feed Intake and Apparent Digestibility. The diets were distributed in restricted amounts (Table 2) according to the requirements of the cows and to provide similar amounts of $\mathrm{NE}_{\mathrm{L}}$ and $\mathrm{CP}$. As diet $\mathrm{C} 0$ had lower $\mathrm{CP}$ and energy concentrations (Table 2), more DM was distributed to the cows on this diet. Table 8 shows that intake of DM and OM was significantly higher for the cows fed diet $\mathrm{C} 0$ than for those fed diets $\mathrm{C} 2$ and OT$\mathrm{HP}$ (differences of DM and OM intakes between diets $\mathrm{C} 0$ and $\mathrm{C} 2$ of 1.7 and $1.4 \mathrm{~kg} / \mathrm{d}$, respectively). Due to limited refusals, intakes of $\mathrm{CP}$ and $\mathrm{NE}_{\mathrm{L}}$ were similar for all treatments.

Table 8 shows fecal apparent digestibility for DM, $\mathrm{OM}$, and CP. The DM and OM digestibility did not sig- nificantly differ between treatments $(P>0.05)$. However, CP digestibility was significantly lower for diet C0 than for diet $\mathrm{C} 2$ (57.7 and $61.8 \%$, respectively). In this experiment, the addition of the mixture of OT and HP failed to significantly affect the diet's CP digestibility.

Milk Production and Milk Composition. Table 9 shows milk production and milk composition. Milk production was similar for diets $\mathrm{C} 0$ and $\mathrm{C} 2$. The OTHP diet increased milk and ECM production (1.8 and $1.3 \mathrm{~kg} / \mathrm{d}$ more, respectively, than for $\operatorname{diet} \mathrm{C} 2 ; P<0.01$ ). The composition of milk produced by cows fed diets $\mathrm{C} 2$ and OT-HP was not significantly different. However, milk fat, milk protein, and milk urea $\mathrm{N}$ content was higher $(P<0.01)$ in cows fed diet $\mathrm{C} 0$. Fat yield was not significantly different among treatments. As a consequence of the higher milk production, protein yield was $5.9 \%$ higher in cows fed diet OT-HP than in those fed diet $\mathrm{C} 2$.

$N$ Balance. Table 10 presents the data for $\mathrm{N}$ outputs and $\mathrm{N}$ balance. Intake of $\mathrm{N}$ and total $\mathrm{N}$ excretion was similar for all diets. Fecal $\mathrm{N}$ was higher and urinary $\mathrm{N}$ was lower with diet $\mathrm{C} 0$ than with diets $\mathrm{C} 2$ and OT-HP $(P<0.01)$. Compared with diet $\mathrm{C} 2$, OT-HP supplementation decreased urinary $\mathrm{N}$ by $6.9 \%(P<0.05)$.

Table 6. Estimation of the $\mathrm{CH}_{4}$ production from the mid-infrared spectra of milk (Vanlierde et al., 2016) in lactating cows fed a total mixed diet (C1) with hop pellet (HP) or oak tannin (OT) supplementation (experiment 1)

\begin{tabular}{|c|c|c|c|c|c|}
\hline \multirow[b]{2}{*}{$\mathrm{CH}_{4}$} & \multicolumn{3}{|c|}{ Diet } & \multirow[b]{2}{*}{ SEM } & \multirow[b]{2}{*}{$P$-value } \\
\hline & $\mathrm{C} 1$ & HP & $\mathrm{OT}$ & & \\
\hline $\mathrm{g} / \mathrm{d}$ & 403.7 & 393.9 & 399.4 & 14.7 & 0.66 \\
\hline $\mathrm{g} / \mathrm{kg}$ of $\mathrm{DM}$ & 21.4 & 20.9 & 21.2 & 0.9 & 0.52 \\
\hline $\mathrm{g} / \mathrm{kg}$ of milk & 15.6 & 14.9 & 15.1 & 1.2 & 0.27 \\
\hline $\mathrm{g} / \mathrm{kg}$ of ECM & 15.5 & 14.9 & 15.1 & 1.1 & 0.28 \\
\hline
\end{tabular}


Table 7. Milk fatty acid composition (\% total fatty acids) in cows fed a total mixed diet (C1) with hop pellet (HP) or oak tannin extract (OT) supplementation (experiment 1)

\begin{tabular}{|c|c|c|c|c|c|}
\hline \multirow[b]{2}{*}{ Item } & \multicolumn{3}{|c|}{ Diet } & \multirow[b]{2}{*}{ SEM } & \multirow[b]{2}{*}{$P$-value } \\
\hline & $\mathrm{C} 1$ & $\mathrm{HP}$ & OT & & \\
\hline $6: 0$ & 2.07 & 2.01 & 2.08 & 0.06 & 0.32 \\
\hline $8: 0$ & 1.49 & 1.44 & 1.48 & 0.06 & 0.43 \\
\hline 10:0 & 3.15 & 3.00 & 3.06 & 0.17 & 0.51 \\
\hline $12: 0$ & 3.59 & 3.24 & 3.25 & 0.17 & 0.08 \\
\hline 14:0 & 12.70 & 12.06 & 12.05 & 0.47 & 0.40 \\
\hline cis-9 14:1 & 1.14 & 1.06 & 1.03 & 0.09 & 0.33 \\
\hline $15: 0$ & 0.90 & 0.89 & 0.87 & 0.04 & 0.81 \\
\hline $16: 0$ & 28.01 & 26.77 & 26.19 & 1.27 & 0.40 \\
\hline cis-9 16:1 & 1.47 & 1.38 & 1.37 & 0.16 & 0.47 \\
\hline $17: 0$ & 0.67 & 0.69 & 0.67 & 0.03 & 0.44 \\
\hline 18:0 & 12.70 & 13.81 & 14.38 & 0.76 & 0.18 \\
\hline cis-9 18:1 & 21.93 & 23.02 & 23.09 & 0.92 & 0.51 \\
\hline cis-11 18:1 & 0.98 & 0.84 & 0.79 & 0.11 & 0.48 \\
\hline trans-9 18:1 & 0.47 & 0.50 & 0.47 & 0.03 & 0.43 \\
\hline trans-11 18:1 & 2.97 & 3.32 & 3.17 & 0.27 & 0.35 \\
\hline cis-9, cis-12 18:2 (LA) & 2.11 & 2.18 & 2.25 & 0.14 & 0.07 \\
\hline cis-9,trans-11 18:2 & 1.29 & 1.30 & 1.22 & 0.09 & 0.70 \\
\hline trans-10,cis-12 18:2 & 0.04 & 0.10 & 0.10 & 0.02 & 0.54 \\
\hline cis-9, cis-12,cis-15 18:3 (ALA) & $1.24^{\mathrm{b}}$ & $1.33^{\mathrm{ab}}$ & $1.46^{\mathrm{a}}$ & 0.11 & 0.04 \\
\hline $20: 0$ & 0.16 & 0.18 & 0.18 & 0.01 & 0.37 \\
\hline Sum of $6: 0$ to $14: 0$ & 23.01 & 21.75 & 21.92 & 0.87 & 0.29 \\
\hline Sum of $\mathrm{C} 18$ fatty acids & 43.78 & 46.39 & 46.92 & 1.76 & 0.34 \\
\hline Sum of trans $\mathrm{C} 18$ fatty acids & 4.81 & 5.21 & 4.95 & 0.36 & 0.52 \\
\hline Total SFA & 65.45 & 64.09 & 64.23 & 1.27 & 0.55 \\
\hline Total UFA & 34.55 & 35.91 & 35.77 & 1.27 & 0.55 \\
\hline PUFA & 5.03 & 5.20 & 5.31 & 0.31 & 0.35 \\
\hline LA:ALA & $1.71^{\mathrm{a}}$ & $1.65^{\mathrm{ab}}$ & $1.56^{\mathrm{b}}$ & 0.04 & 0.02 \\
\hline
\end{tabular}

${ }^{\mathrm{a}, \mathrm{b}}$ Means within a row with no common superscript differ $(P<0.05)$.

Milk $\mathrm{N}$ was higher in cows fed diet $\mathrm{C} 0$ than in cows fed diet $\mathrm{C} 2$. Incorporation of $\mathrm{OT}$ and $\mathrm{HP}$ in diet $\mathrm{C} 2$ was associated with an improvement of the efficiency of $\mathrm{N}$ utilization for milk production (from $33.5 \%$ to $35.1 \%$ of N intake; $P<0.01$ ).

Enteric $\mathrm{CH}_{4}$ Production. Compared with $\mathrm{C} 0$, the enteric $\mathrm{CH}_{4}$ production of $\mathrm{C} 2$, which included rolled barley and extruded linseed, was significantly lower when expressed in grams per day $(-15 \%)$, grams per kilogram of milk (-15\%), or grams per kilogram of ECM $(-14 \%)$ and tended to be lower when expressed in grams per kilogram of DMI $(P=0.10$; Table 11). Supplementation of diet $\mathrm{C} 2$ with the OT-HP mixture did not significantly influence enteric $\mathrm{CH}_{4}$ production.

Milk Fatty Acid Composition. The treatments significantly $(P<0.05)$ affected all milk fatty acids (Table 12). Compared with diet $\mathrm{C} 0$, milk fat produced by cows on diet $\mathrm{C} 2$, which was supplemented with $6.7 \%$

Table 8. Intake and fecal apparent digestibility of nutriments in lactating cows fed a total mixed diet without extruded linseed $(\mathrm{C} 0)$, with extruded linseed $(\mathrm{C} 2)$, or with extruded linseed and oak tannin and hop pellet (OT-HP) supplementation (experiment 2)

\begin{tabular}{lccccr}
\hline & \multicolumn{5}{c}{ Diet } \\
\cline { 2 - 3 } Item & $\mathrm{C} 0$ & $\mathrm{C} 2$ & OT-HP & SEM & P-value \\
\hline Intake & & & & \\
DM, kg/d & $20.1^{\mathrm{a}}$ & $18.4^{\mathrm{b}}$ & $18.5^{\mathrm{b}}$ & 0.11 & $<0.01$ \\
$\mathrm{OM}, \mathrm{kg} / \mathrm{d}$ & $18.6^{\mathrm{a}}$ & $17.2^{\mathrm{b}}$ & $17.3^{\mathrm{b}}$ & 0.09 & $<0.01$ \\
$\mathrm{CP}, \mathrm{kg} / \mathrm{d}$ & 2.62 & 2.60 & 2.62 & 0.02 & 0.61 \\
$\mathrm{NE}, \mathrm{Mcal} / \mathrm{d}$ & 30.6 & 30.5 & 30.7 & 0.18 & 0.82 \\
Digestibility, \% & 68.0 & 68.2 & 68.1 & 0.53 & 0.88 \\
DM & 70.8 & 71.0 & 70.9 & 0.49 & 0.89 \\
OM & $57.7^{\mathrm{b}}$ & $61.8^{\mathrm{a}}$ & $61.2^{\mathrm{a}}$ & 0.86 & $<0.01$ \\
$\mathrm{CP}$ & & & & \\
\hline
\end{tabular}

${ }^{\mathrm{a}, \mathrm{b}}$ Means within a row with no common superscript differ $(P<0.05)$. 
Table 9. Milk production and milk composition of lactating cows fed a total mixed diet without extruded linseed ( $\mathrm{C} 0)$, with extruded linseed (C2), or with extruded linseed and oak tannin and hop pellet (OT-HP) supplementation (experiment 2)

\begin{tabular}{|c|c|c|c|c|c|}
\hline \multirow[b]{2}{*}{ Item } & \multicolumn{3}{|c|}{ Diet } & \multirow[b]{2}{*}{ SEM } & \multirow[b]{2}{*}{$P$-value } \\
\hline & $\mathrm{C} 0$ & $\mathrm{C} 2$ & OT-HP & & \\
\hline \multicolumn{6}{|l|}{ Production, $\mathrm{kg} / \mathrm{d}$} \\
\hline Milk & $29.2^{\mathrm{b}}$ & $29.7^{\mathrm{b}}$ & $31.5^{\mathrm{a}}$ & 0.54 & $<0.01$ \\
\hline $\mathrm{ECM}^{1}$ & $29.4^{\mathrm{ab}}$ & $29.0^{\mathrm{b}}$ & $30.3^{\mathrm{a}}$ & 0.59 & 0.02 \\
\hline \multicolumn{6}{|l|}{ Composition } \\
\hline Fat, $\%$ & $4.09^{\mathrm{a}}$ & $3.87^{\mathrm{b}}$ & $3.79^{\mathrm{b}}$ & 0.15 & $<0.01$ \\
\hline Protein, $\%$ & $3.28^{\mathrm{a}}$ & $3.10^{\mathrm{b}}$ & $3.10^{\mathrm{b}}$ & 0.07 & $<0.01$ \\
\hline MUN, mg/dL & $3.13^{\mathrm{a}}$ & $2.14^{\mathrm{b}}$ & $1.71^{\mathrm{b}}$ & 0.24 & $<0.01$ \\
\hline \multicolumn{6}{|l|}{ Yield, g/d } \\
\hline Fat & 1,191 & 1,153 & 1,190 & 44.8 & 0.31 \\
\hline Protein & $955^{\mathrm{a}}$ & $922^{\mathrm{b}}$ & $976^{\mathrm{a}}$ & 18.2 & $<0.01$ \\
\hline
\end{tabular}

${ }^{\mathrm{a}, \mathrm{b}}$ Means within a row with no common superscript differ $(P<0.05)$.

${ }^{1} \mathrm{ECM}(\mathrm{kg})=[0.337+(0.116 \times \%$ fat $)+(0.06 \times \%$ protein $)] \times$ production $(\mathrm{kg})(\mathrm{CVB}, 2008)$.

extruded linseeds on a DM basis, contained significantly less short- and medium-chain fatty acids. The sum of 6:0 to 14:0 fatty acids was decreased by $16 \%$ and palmitic acid (16:0) by $26 \%$. On the other hand, longchain fatty acids were greatly increased. Stearic acid (18:0) was increased by $50 \%$ and oleic acid (cis-9 18:1) by $36 \%$. Even more strikingly, vaccenic acid (trans-11 18:1) increased by $285 \%$, rumenic acid (cis-9,trans-11 $18: 2$ ) by $235 \%$, and ALA by $100 \%$. Total UFA improved by $42 \%$, and the LA:ALA ratio decreased by $45 \%$.

Moreover, supplementation of diet $\mathrm{C} 2$ with the OTHP mixture further improved the milk fatty acid composition. The sum of 6:0 to 14:0 fatty acids decreased by $4 \%$, and palmitic acid decreased by $8 \%$. Stearic, oleic, and vaccenic acids increased by $7 \%$, and ALA increased by $16 \%$. Total UFA were further improved by $6 \%$.

\section{DISCUSSION}

\section{Characteristics of the Control Diets}

We designed the control diets $\mathrm{C} 1$ and $\mathrm{C} 2$ (Tables 1 and 2) primarily to minimize $\mathrm{CH}_{4}$ emissions and maximize $\mathrm{N}$ efficiency and secondarily to improve the fatty acid composition of milk. Compared with dietary fiber, incorporation of barley in the diet introduced starch, which may result in reduced enteric $\mathrm{CH}_{4}$ production because it favors production of propionate in the rumen (Benchaar et al., 2001; Bannink et al., 2006), creating an alternative hydrogen sink to methanogenesis.

Supplementation of the diet with extruded linseed at a level of $6.7 \%$ of the DM introduced $40 \mathrm{~g}$ of fatty acids/kg of diet DM. Most of the many studies that have

Table 10. Nitrogen balance in lactating cows fed a total mixed diet without extruded linseed (C0), with extruded linseed (C2), or with extruded linseed and oak tannin and hop pellet (OT-HP) supplementation (experiment 2)

\begin{tabular}{|c|c|c|c|c|c|}
\hline \multirow[b]{2}{*}{ Item } & \multicolumn{3}{|c|}{ Diet } & \multirow[b]{2}{*}{ SEM } & \multirow[b]{2}{*}{$P$-value } \\
\hline & $\mathrm{C} 0$ & $\mathrm{C} 2$ & OT-HP & & \\
\hline $\mathrm{N}$ intake, $\mathrm{g} / \mathrm{d}$ & 419 & 415 & 419 & 3.2 & 0.61 \\
\hline \multicolumn{6}{|l|}{ Fecal N } \\
\hline $\mathrm{g} / \mathrm{d}$ & $177^{\mathrm{a}}$ & $158^{\mathrm{b}}$ & $162^{\mathrm{b}}$ & 3.8 & $<0.01$ \\
\hline$\%$ of $\mathrm{N}$ intake & 42.2 & 38.1 & 38.7 & 0.9 & $<0.01$ \\
\hline \multicolumn{6}{|l|}{ Urinary N } \\
\hline $\mathrm{g} / \mathrm{d}$ & $77^{\mathrm{c}}$ & $102^{\mathrm{a}}$ & $95^{\mathrm{b}}$ & 4.5 & $<0.01$ \\
\hline$\%$ of $\mathrm{N}$ intake & 18.4 & 24.6 & 22.7 & 1.08 & $<0.01$ \\
\hline \multicolumn{6}{|l|}{ Total N excretion } \\
\hline $\mathrm{g} / \mathrm{d}$ & 254 & 260 & 257 & 3.4 & 0.10 \\
\hline$\%$ of $\mathrm{N}$ intake & 60.6 & 62.7 & 61.4 & 0.8 & 0.10 \\
\hline \multicolumn{6}{|l|}{ Milk N } \\
\hline $\mathrm{g} / \mathrm{d}$ & $145^{\mathrm{a}}$ & $139^{\mathrm{b}}$ & $147^{\mathrm{a}}$ & 2.6 & $<0.01$ \\
\hline$\%$ of $\mathrm{N}$ intake & 34.6 & 33.5 & 35.1 & 0.6 & $<0.01$ \\
\hline
\end{tabular}

$\overline{\mathrm{a}, \mathrm{b}}$ Means within a row with no common superscript differ $(P<0.05)$. 
Table 11. Methane production in lactating cows fed a total mixed diet without extruded linseed (C0), with extruded linseed (C2), or with extruded linseed and oak tannin and hop pellet (OT-HP) supplementation (experiment 2)

\begin{tabular}{|c|c|c|c|c|c|}
\hline \multirow[b]{2}{*}{ Item } & \multicolumn{3}{|c|}{ Diet } & \multirow[b]{2}{*}{ SEM } & \multirow[b]{2}{*}{$P$-value } \\
\hline & $\mathrm{C} 0$ & $\mathrm{C} 2$ & OT-HP & & \\
\hline \multicolumn{6}{|l|}{$\overline{\mathrm{CH}_{4}}$} \\
\hline $\mathrm{g} / \mathrm{d}$ & $365^{\mathrm{a}}$ & $311^{\mathrm{b}}$ & $315^{\mathrm{b}}$ & 25.0 & $<0.01$ \\
\hline $\mathrm{g} / \mathrm{kg}$ of DMI & 18.7 & 17.3 & 17.3 & 1.3 & 0.10 \\
\hline $\mathrm{g} / \mathrm{kg}$ of milk & $14.0^{\mathrm{a}}$ & $11.9^{\mathrm{b}}$ & $11.2^{\mathrm{b}}$ & 0.8 & $<0.01$ \\
\hline $\mathrm{g} / \mathrm{kg}$ of $\mathrm{ECM}^{1}$ & $14.0^{\mathrm{a}}$ & $12.0^{\mathrm{b}}$ & $11.4^{\mathrm{b}}$ & 0.7 & $<0.01$ \\
\hline $\mathrm{DMI},{ }^{2} \mathrm{~kg} / \mathrm{d}$ & 19.5 & 17.9 & 18.2 & 0.1 & $<0.01$ \\
\hline \multicolumn{6}{|l|}{ Production, ${ }^{2} \mathrm{~kg} / \mathrm{d}$} \\
\hline Milk & $25.9^{\mathrm{a}}$ & $26.4^{\mathrm{a}}$ & $28.0^{\mathrm{b}}$ & 0.5 & $<0.01$ \\
\hline $\mathrm{ECM}^{1}$ & $26.1^{\mathrm{a}}$ & $26.0^{\mathrm{a}}$ & $27.7^{\mathrm{b}}$ & 0.4 & $<0.01$ \\
\hline
\end{tabular}

a,b Means within a row with no common superscript differ $(P<0.05)$.

${ }^{1} \mathrm{ECM}(\mathrm{kg})=[0.337+(0.116 \times \%$ fat $)+(0.06 \times \%$ protein $)] \times$ production $(\mathrm{kg})(\mathrm{CVB}, 2008)$.

${ }^{2} \mathrm{DMI}$ and production corresponding to the days of $\mathrm{CH}_{4}$ effective recordings (minimum of $4 \mathrm{~d}$ ).

investigated the effect of linseed or linseed oil supply on enteric $\mathrm{CH}_{4}$ production have shown a significant reduction of daily $\mathrm{CH}_{4}$ emissions when dairy cows are fed linseed fatty acids (Martin et al., 2008, 2016; Beauchemin et al., 2009; Mohammed et al., 2011). In addition, feeding linseed has been shown to decrease milk con- centrations in SFA and increase those in UFA-more specifically ALA and CLA-compared with a control diet without linseed (Gonthier et al., 2005; Akraim et al., 2007). For these reasons, linseed has become the standard solution in Europe for improving the fatty acid profile of cow milk. In experiment 2 , we used a

Table 12. Milk fatty acid composition ( $\mathrm{g} / 100 \mathrm{~g}$ of fatty acids) in cows fed a total mixed diet without extruded linseed $(\mathrm{C} 0)$, with extruded linseed $(\mathrm{C} 2)$, or with extruded linseed and oak tannin and hop pellet (OT-HP) supplementation (experiment 2)

\begin{tabular}{|c|c|c|c|c|c|}
\hline \multirow[b]{2}{*}{ Item } & \multicolumn{3}{|c|}{ Diet } & \multirow[b]{2}{*}{ SEM } & \multirow[b]{2}{*}{$P$-value } \\
\hline & $\mathrm{C} 0$ & $\mathrm{C} 2$ & OT-HP & & \\
\hline $6: 0$ & $2.83^{\mathrm{a}}$ & $2.73^{\mathrm{b}}$ & $2.63^{\mathrm{c}}$ & 0.08 & $<0.01$ \\
\hline $8: 0$ & $1.72^{\mathrm{a}}$ & $1.54^{\mathrm{b}}$ & $1.47^{\mathrm{c}}$ & 0.06 & $<0.01$ \\
\hline 10:0 & $3.71^{\mathrm{a}}$ & $2.92^{\mathrm{b}}$ & $2.75^{\mathrm{c}}$ & 0.13 & $<0.01$ \\
\hline $12: 0$ & $4.06^{\mathrm{a}}$ & $2.99^{\mathrm{b}}$ & $2.84^{\mathrm{c}}$ & 0.12 & $<0.01$ \\
\hline 14:0 & $13.29^{\mathrm{a}}$ & $11.27^{\mathrm{b}}$ & $10.92^{c}$ & 0.21 & $<0.01$ \\
\hline cis-9 14:1 & $0.97^{\mathrm{a}}$ & $0.73^{\mathrm{b}}$ & $0.74^{\mathrm{b}}$ & 0.08 & $<0.01$ \\
\hline $15: 0$ & $2.02^{\mathrm{a}}$ & $1.46^{\mathrm{b}}$ & $1.42^{\mathrm{b}}$ & 0.06 & $<0.01$ \\
\hline 16:0 & $37.77^{\mathrm{a}}$ & $28.07^{\mathrm{b}}$ & $25.91^{\mathrm{c}}$ & 0.96 & $<0.01$ \\
\hline cis-9 $16: 1$ & $1.68^{\mathrm{a}}$ & $1.24^{\mathrm{b}}$ & $1.21^{\mathrm{b}}$ & 0.04 & $<0.01$ \\
\hline $17: 0$ & $2.00^{\mathrm{a}}$ & $1.77^{\mathrm{b}}$ & $1.76^{\mathrm{b}}$ & 0.01 & $<0.01$ \\
\hline 18:0 & $8.52^{\mathrm{c}}$ & $12.81^{\mathrm{b}}$ & $13.68^{\mathrm{a}}$ & 0.35 & $<0.01$ \\
\hline cis-9 18:1 & $15.72^{\mathrm{c}}$ & $21.45^{\mathrm{b}}$ & $22.92^{\mathrm{a}}$ & 0.68 & $<0.01$ \\
\hline cis-11 18:1 & 1.05 & 1.04 & 1.08 & 0.04 & 0.05 \\
\hline trans-9 $18: 1$ & $0.35^{\mathrm{b}}$ & $0.69^{\mathrm{a}}$ & $0.68^{\mathrm{a}}$ & 0.03 & $<0.01$ \\
\hline trans-11 18:1 & $1.01^{\mathrm{b}}$ & $4.00^{\mathrm{a}}$ & $4.27^{\mathrm{a}}$ & 0.22 & $<0.01$ \\
\hline cis-9,cis-12 18:2 (LA) & $1.66^{\mathrm{c}}$ & $1.82^{\mathrm{b}}$ & $1.99^{\mathrm{a}}$ & 0.10 & $<0.01$ \\
\hline cis-9,trans-11 18:2 & $0.40^{\mathrm{c}}$ & $1.34^{\mathrm{b}}$ & $1.44^{\mathrm{a}}$ & 0.08 & $<0.01$ \\
\hline trans -10, cis -12 18:2 & $0.05^{\mathrm{c}}$ & $0.10^{\mathrm{b}}$ & $0.11^{\mathrm{a}}$ & 0.01 & $<0.01$ \\
\hline cis-9,cis-12,cis-15 18:3 (ALA) & $0.51^{\mathrm{c}}$ & $1.02^{\mathrm{b}}$ & $1.18^{\mathrm{a}}$ & 0.06 & $<0.01$ \\
\hline $20: 0$ & 0.15 & 0.16 & 0.16 & 0.01 & 0.06 \\
\hline Sum of $6: 0$ to $14: 0$ & $25.61^{\mathrm{a}}$ & $21.45^{\mathrm{b}}$ & $20.61^{\mathrm{c}}$ & 0.51 & $<0.01$ \\
\hline Sum of C18 fatty acid & $29.48^{\mathrm{c}}$ & $44.79^{\mathrm{b}}$ & $47.88^{\mathrm{a}}$ & 0.98 & $<0.01$ \\
\hline Sum of trans C18 fatty acid & $2.02^{\mathrm{b}}$ & $6.65^{\mathrm{a}}$ & $7.01^{\mathrm{a}}$ & 0.30 & $<0.01$ \\
\hline Total SFA & $75.41^{\mathrm{a}}$ & $65.02^{\mathrm{b}}$ & $62.82^{\mathrm{c}}$ & 0.91 & $<0.01$ \\
\hline Total UFA & $24.59^{\mathrm{c}}$ & $34.98^{\mathrm{b}}$ & $37.18^{\mathrm{a}}$ & 0.91 & $<0.01$ \\
\hline PUFA & $3.15^{\mathrm{c}}$ & $5.11^{\mathrm{b}}$ & $5.56^{\mathrm{a}}$ & 0.21 & $<0.01$ \\
\hline LA:ALA & $3.28^{\mathrm{a}}$ & $1.79^{\mathrm{b}}$ & $1.70^{\mathrm{b}}$ & 0.06 & $<0.01$ \\
\hline
\end{tabular}

${ }^{\mathrm{a}-\mathrm{c}}$ Means within a row with no common superscript differ $(P<0.05)$. 
control diet without linseed and barley $(\mathrm{C} 0)$ to quantify the effect of these feedstuffs on $\mathrm{CH}_{4}$ production and milk fatty acid composition.

We deliberately kept the CP content of the control diets (13.1 and $14.1 \%$ of the DM in experiments 1 and 2 , respectively) low. These levels have been found to reduce $\mathrm{N}$ excretion (Colmenero and Broderick, 2006; Mutsvangwa et al., 2016). Moreover, the RDP balance value of the diets was close to 0 to make it possible to limit the excess of RDP compared with fermentable carbohydrates. This is also likely to limit urinary $\mathrm{N}$ emissions by dairy cows.

\section{Nutrient Apparent Digestibility}

The treatments did not affect the apparent fecal digestibility of DM or OM. Supplementation of the diet with OT significantly decreased CP digestibility in experiment 1 (60.3 vs. $61.3 \%)$ but not in experiment 2. When supplementing the corn silage- and alfalfa silage-based diet with quebracho tannins, Aguerre et al. (2016) observed a linear decrease in fecal CP digestibility with increasing levels of dietary tannins in dairy cows. At a level of tannins similar to that in our experiments $(0.5 \%$ of $\mathrm{DM})$, the decrease of $\mathrm{CP}$ digestibility was higher ( $4.1 \%$ vs. $1.6 \%$ in experiment 1$)$. Other studies have also reported lower CP digestibility when tannins are added to the diet (Dawson et al., 1999; Ahnert et al., 2015). The main effect of tannins on proteins is based on their ability to form hydrogen bonds that are stable at rumen $\mathrm{pH}$ but dissociate when the $\mathrm{pH}$ decreases below 3.5 (e.g., in the abomasum) or is greater than 8 (e.g., in the duodenum; Frutos et al., 2004). However, many authors have reported that tannins exert a negative effect on nutrient absorption from the small intestine (Silanikove et al., 1994, 2001; McNabb et al., 1998), which could be due to the persistence in the intestine of tannin-protein complexes, the formation of tannin-digestive enzyme complexes, or changes in intestinal absorption due to the interaction of tannins with intestinal mucosa (Frutos et al., 2004). According to Mueller-Harvey (2006), the strength of tannin-protein binding and the source of tannins influence the response of fecal digestibility of CP.

In experiment 2, the $\mathrm{CP}$ fecal digestibility of diet $\mathrm{C} 0$ was significantly lower than that of $\mathrm{C} 2$. We believe this difference is probably attributable to the composition of the diets. According to Baumont et al. (2018), among the ingredients that compose $\mathrm{C} 0$ and $\mathrm{C} 2$ diets, those with the lowest $\mathrm{CP}$ digestibility are corn silage and sugar beet pulp. Given that these 2 ingredients were in higher proportions in $\mathrm{C} 0$, it makes sense that the $\mathrm{CP}$ digestibility of $\mathrm{C} 0$ was lower than that of $\mathrm{C} 2$.

\section{Milk Production and Milk Composition}

In experiment 1, supplementation of the diet with HP or OT did not affect milk production or milk composition. In experiment 2, supplementation of the diet with HP and OT in combination increased milk production and protein yield. To our knowledge, no information has been previously published on the effect of hops on milk production and milk composition in cows. On the other hand, supplementation of diets with condensed tannin extracts from quebracho trees (Benchaar et al., 2008; Aguerre et al., 2016), Acacia mearnsii (Griffiths et al., 2013), or tamarind seed husk (Bhatta et al., 2000) at doses similar to ours had no effect on milk production or composition.

As already observed with a diet enriched with linseed (Focant et al., 1998; Hurtaud et al., 2010) and with linseed oil (Benchaar et al., 2015), milk fat and milk protein were significantly lower for diet $\mathrm{C} 2$, which contained linseed and barley, than for $\mathrm{C} 0$ (experiment 2). According to the biohydrogenation (BH) theory of milk fat depression (Bauman and Griinari, 2003), trans-10 fatty acids produced in the rumen of cows fed diets including oilseeds or oils supplements are responsible for the reduced milk fat content. Ferlay et al. (2013), who studied the effects of linseed supplementation on milk fat content, observed that the trans-10 18:1, trans11,cis-15 18:2, and ALA percentages were negatively correlated with the milk fat content for hay-based diets. In experiment 2, we unfortunately could not separate or identify the trans-10 18:1 or the trans-11,cis-15 18:2, but the trans-10,cis-12 18:2 and ALA were significantly higher with rations supplemented with extruded linseed. Numerous data show that increasing the fat content of diets generally decreases protein levels in milk. According to $\mathrm{Wu}$ and Huber (1994), the decrease could be attributed to a lack of available AA in the mammary gland for protein synthesis. As in experiment 2, Petit et al. (2005) found lower levels of milk protein in cows fed flaxseed than in those fed the control diets. This would correspond with the results of Gonthier et al. (2004), who showed that flaxseed reduced the duodenal flow of microbial proteins, thus decreasing the amount of microbial AA available for milk protein synthesis.

\section{N Balance}

Treatments with OT with (experiment 2) or without (experiment 1) HP reduced urinary $\mathrm{N}$ excretion compared with the control. The fact that the combination of OT and HP did not have a greater effect on urinary $\mathrm{N}$ than OT alone suggests that the protein-saving effect observed in this study can be attributed only to OT. 
Published data on the effect of hops on protein degradation are scarce and limited to in vitro experiments (Flythe, 2009; Narvaez et al., 2013; Lavrenčič et al., 2014). Flythe (2009) reported that hops inhibited the growth and $\mathrm{NH}_{3}$ production of pure cultures of 3 species of hyper- $\mathrm{NH}_{3}$-producing bacteria and that a similar effect could be expected in the rumen, although these 3 species may not represent all rumen hyper- $\mathrm{NH}_{3}$ producing bacteria. Narvaez et al. (2013) observed that a hop extract added to a grower diet for feedlot cattle decreased $\mathrm{NH}_{3}-\mathrm{N}$ and microbial protein production during 48-h incubations. Lavrenčič et al. (2014) reported that $\mathrm{CP}$ degradability of substrates decreased with increasing concentrations of hop and suggested in turn that the amount of RUP may be increased by this treatment. However, HP added to a mixture of grass silage and white lupine seeds (Lupinus albus) did not lead to any reduction of the $\mathrm{NH}_{3}-\mathrm{N}$ concentration after 24-h incubations in rumen fluids (Dang Van et al., 2018).

The effects of tannins on $\mathrm{N}$ metabolism are well documented in the literature. Researchers have established that dietary tannins (condensed or hydrolysable) may protect dietary proteins from microbial degradation by interacting with them. This protective effect is thought to cause a lowering of the ruminal $\mathrm{NH}_{3}$ concentration and an increasing ruminal escape of dietary proteins (Mueller-Harvey, 2006; Bhatta et al., 2009; Patra and Saxena, 2011). Several in situ studies have demonstrated the reduction of protein degradation in the rumen. In particular, the degradation rate of soybean $\mathrm{N}$ decreased linearly with the level of Cistus ladanifer extract (Dentinho et al., 2007) or with treatment with quebracho tannins (Frutos et al., 2000).

Feeding OT increased fecal $\mathrm{N}$ excretion but reduced urinary $\mathrm{N}$ excretion. Our results thus confirmed, with $\mathrm{OT}$, the shift in $\mathrm{N}$ partitioning from urine to feces that has been reported in studies with tannin extracts from quebracho (Dawson et al., 1999; Ahnert et al., 2015; Aguerre et al., 2016), tamarind seed husk (Bhatta et al., 2000), or Acacia mearnsii (Grainger et al., 2009). Shifting the excretion pattern of $\mathrm{N}$ from urine to feces is beneficial environmentally. Fecal $\mathrm{N}$ is mainly in an organic form, which is less volatile, whereas urinary $\mathrm{N}$ is largely in the form of urea, which is more rapidly hydrolyzed to $\mathrm{NH}_{3}$ and nitrified to $\mathrm{NO}_{3}{ }^{-}$(Dijkstra et al., 2013). The $\mathrm{NO}_{3}{ }^{-}$may leach into groundwater, causing water pollution, and is converted into the greenhouse gas $\mathrm{N}_{2} \mathrm{O}$ (Eckard et al., 2010).

In experiment 2 , diet $\mathrm{C} 0$, which was rich in sugar beet pulp, led to lower urinary $\mathrm{N}$ excretion, higher fecal $\mathrm{N}$ excretion, and higher milk $\mathrm{N}$ than $\operatorname{diet} \mathrm{C} 2$, which was rich in linseed and barley. According to Baumont et al. (2018), the effective degradability of dried beet pulp
$\mathrm{N}$ is significantly lower than that of barley $\mathrm{N}(52 \%$ vs. $71 \%$ ). This difference implies a reduction in $\mathrm{NH}_{3}$ release in the rumen, which may in turn decrease urinary $\mathrm{N}$ excretion.

\section{Enteric $\mathrm{CH}_{4}$ Production}

Production of acetate and butyrate liberates hydrogen, whereas propionate serves as a net hydrogen sink. As a consequence, diets that increase propionate and decrease acetate in the rumen are often associated with a reduction in ruminal methanogenesis given that less hydrogen is available to methanogens for reducing $\mathrm{CO}_{2}$ to $\mathrm{CH}_{4}$ (Hassanat et al., 2013). In in vitro incubations, Narvaez et al. (2013) and Lavrenčič et al. (2015) observed a decrease in the acetate:propionate ratio when hops were added to diets. The reduced acetate: propionate ratio indicates a shift in microbial populations toward propionate-producing bacteria and can be attributed to an inhibition of the activity of grampositive but not gram-negative bacteria (Narvaez et al., 2013). The ionophore-like activity of hops, similar to that of monensin, has been reported in previous studies (Simpson, 1993; Behr and Vogel, 2009). The decrease in $\mathrm{CH}_{4}$ production by hops observed by Narvaez et al. (2013) has also been attributed to an inhibition of methanogens and redirection of $\mathrm{H}_{2}$ from $\mathrm{CH}_{4}$ toward propionate production. In contrast to the published in vitro data mentioned above, a $56 \mathrm{~g} / \mathrm{d}$ supplementation of the cow's ration with HP had no effect on the production of $\mathrm{CH}_{4}$. To our knowledge, there is no published information on the effect of hops on $\mathrm{CH}_{4}$ production in vivo.

Supplementation of our control diets with $169 \mathrm{~g} / \mathrm{d}$ ( $0.9 \%$ of DM) of OT alone or in combination with $56 \mathrm{~g}$ of $\mathrm{HP} / \mathrm{d}$ did not affect $\mathrm{CH}_{4}$ production when expressed in grams per day, grams per kilogram of DM, or grams per kilogram of milk. In contrast to our study, many published data have indicated that ruminal $\mathrm{CH}_{4}$ production is reduced by tannin addition. Tannins, as feed supplements or as tanniferous plants generally, show a potential for reducing $\mathrm{CH}_{4}$ emission by up to $20 \%$ (Waghorn et al., 2002; Zhou et al., 2011; Staerfl et al., 2012). According to Goel and Makkar (2012), the antimethanogenic effect of tannins depends on the dietary concentration and is positively related to the number of hydroxyl groups in their structure. Hydrolyzable tannins decrease methanogenesis, either directly by reducing the archaeal population or indirectly by reducing the protozoal population, thereby reducing archaea symbiotically associated with the protozoa (Bhatta et al., 2009; Patra and Saxena, 2011). On the other hand, the effect of condensed tannins on $\mathrm{CH}_{4}$ production ap- 
pears to be due to an inhibition of fiber digestion, but the effects usually depend on the species of microorganism and on the concentration, type, or source of tannin (Patra and Saxena, 2011).

The lack of tannin effect on $\mathrm{CH}_{4}$ emissions in our trials suggests that a direct interference on methanogenic archaea and protozoa population did not occur. Beauchemin et al. (2007), using condensed tannin extract from quebracho trees at levels of 1 and $2 \%$ of the diet DM, also found no effect on $\mathrm{CH}_{4}$ production in heifers.

In experiment 2 , the production of $\mathrm{CH}_{4}$ with $\mathrm{C} 2$ was $15 \%$ lower than with diet $\mathrm{C} 0$, expressed in grams per day or in grams per kilogram of DMI. Three major differences distinguished the 2 diets: compared with $\mathrm{C} 0$, C2 contained rolled barley ( $10 \%$ of DM), much less beet pulp ( $2 \%$ vs. $21 \%$ of DM), and above all, extruded linseed $(6.7 \%$ of DM). Each of these differences favors a decrease in methanogenesis. Barley is known to be a source of rapidly fermentable starch. Compared with dietary fiber, starch fermentation in the rumen may result in reduced enteric $\mathrm{CH}_{4}$ production because the fermentation of starch favors propionate production (Bannink et al., 2006), creating an alternative hydrogen sink to methanogenesis (Hatew et al., 2015). On a DM basis, the starch content of diets $\mathrm{C} 0$ and $\mathrm{C} 2$ was 12.5 and $20.2 \%$, respectively.

Regarding sugar beet pulp, a recent meta-analysis on its use in dairy cows (Münnich et al., 2017) concluded that feeding beet pulp at a level above $200 \mathrm{~g} / \mathrm{kg}$ of diet DM generally increases acetate:propionate ratio. Substituting various concentrations of dried sugar beet pulp for barley grain in the diet of Holstein steers also produced a higher acetate:propionate ratio in the rumen fluid (Mojtahedi and Mesgaran, 2011).

The PUFA are among the most promising dietary alternatives able to depress ruminal methanogenesis (Martin et al., 2006). At an inclusion level of $10 \%$ of linseed on a DM basis, Beauchemin et al. (2009) and Martin et al. (2016) observed a decrease in daily $\mathrm{CH}_{4}$ production of $13 \%$. In response to the increase in linseed supply from 0 to $15 \%$ of DM, the ruminal acetate: propionate ratio and the total protozoa concentration decreased linearly (Martin et al., 2016). Similar changes in rumen activity were also observed by Benchaar et al. (2015) following linseed oil supplementation. Considering the literature cited above, the $15 \%$ decrease in $\mathrm{CH}_{4}$ production observed with diet $\mathrm{C} 2$ compared with diet C0 appears consistent with an extruded linseed intake of $6.7 \%$ on a DM basis, supplemented by the effects of barley intake and the sharp decrease in beet pulp ingestion.

\section{Milk Fatty Acid Composition}

To our knowledge, there is no published scientific data on the effect of hops on the BH of fatty acids in the rumen. Hop $\alpha$ - and $\beta$-acids have been shown to inhibit most gram-positive bacteria in a manner similar to monensin (Narvaez et al., 2013). The potential of ionophores to decrease $\mathrm{BH}$ has been demonstrated in vitro (Van Nevel and Demeyer, 1995). In in vivo studies of cows eating a diet supplemented with the ionophore monensin, the resultant milk fatty acid composition suggested a depressed ruminal BH: SFA including C16:0 decreased, and MUFA (specially the 18:1 trans isomers), PUFA, and CLA increased (Sauer et al., 1998; Odongo et al., 2007). Martineau et al. (2008) observed a decrease in the rate of $\mathrm{BH}$ of $\mathrm{C} 18: 3$ from linseed when the diet was supplemented with monensin. Because the antimicrobial activity of hops is similar to that of monensin, we expected to observe an inhibition of fatty acids $\mathrm{BH}$ resulting in higher UFA levels in milk; however, hops alone at the tested dose $(2.9 \mathrm{~g}$ of $\mathrm{HP} / \mathrm{kg}$ of DM) had no significant effect on the fatty acid profile of milk (experiment 1). Either this dose was too low or the rumen microbes were adapted to hops.

Condensed tannins may bind to rumen microbes or to their enzymes and may thereby inhibit the growth and activity of rumen microbes responsible for BH (Min et al., 2003). Buccioni et al. (2015) showed in dairy ewes that condensed tannins from quebracho inhibit Butyrivibrio proteoclasticus, a bacterial species involved in ruminal BH. Kronberg et al. (2007) reported that quebracho tannin $(200 \mathrm{~g} / \mathrm{kg})$ reduces $\mathrm{BH}$ of ALA in linseed. Studies on the effects of tannins on milk fatty acid profile are more limited and inconsistent. Henke et al. (2017) reported that the addition of quebracho tannin (15 and $30 \mathrm{~g} / \mathrm{kg}$ of DM) to diets of lactating dairy cows modulates the fatty acid profile of milk fat with a dose-dependent effect. The concentrations of LA and ALA were increased and concentrations of myristic acid (14:0) and palmitic acid (16:0) were reduced at the highest dosage of tannin. On the other hand, Benchaar and Chouinard (2009) did not observe any changes in milk fatty acid composition with a supplement of quebracho tannin extract $(150 \mathrm{~g} / \mathrm{d}$; i.e., $4.5 \mathrm{~g} / \mathrm{kg}$ of DM) in dairy cows, and Dschaak et al. (2011) concluded that, in general, supplementation of condensed tannins had minor effects on milk fatty acid profile. In experiment 1 , OT alone at the rate of $169 \mathrm{~g} / \mathrm{d}(8.75 \mathrm{~g} / \mathrm{kg}$ of DM) incorporated in the OT diet containing extruded linseed affected the ALA concentration, which was increased by $18 \%$ compared with diet $\mathrm{C} 1$. The latter indicates that OT probably inhibit the first isomerization step 
of ruminal BH of ALA. However, the effect on ALA concentration in milk remains very limited. All these findings show the low potential of tannins extracts to alter the ruminal $\mathrm{BH}$ process and to modify the fatty acid profile of milk fat when these extracts are used at practical feeding rates in dairy cow diets.

When OT and HP were used in combination in a diet enriched in extruded linseed (experiment 2), changes in fatty acid profile were more pronounced. The concentration of SFA from 6:0 to 16:0 was decreased from $3.1 \%$ for $14: 0$ to $7.7 \%$ for $16: 0$. In contrast, the UFA and PUFA were increased by 6.3 and $8.8 \%$, respectively. In particular, rumenic acid and ALA, which are nutritionally beneficial for the health of consumers, were increased by 7.4 and $15.7 \%$, respectively. All these results suggest that the effects of OT and HP on the bacteria responsible for the rumen $\mathrm{BH}$ could be additive.

Considerable evidence exists that milk fatty acid composition can be modulated by adding oilseeds to the diet of dairy cows (Chilliard et al., 2007). In addition to being effective in limiting $\mathrm{CH}_{4}$ production by dairy cows, several meta-analyses have shown the ability of oilseeds and particularly linseed to improve the nutritional composition of milk fatty acids (Glasser et al., 2008; Leduc et al., 2017; Meignan et al., 2017).

On the basis of their review, Meignan et al. (2017) concluded that for a daily supplement of $1 \mathrm{~kg}$ of extruded linseed, which is close to the amount added to our diets $(1.3 \mathrm{~kg} / \mathrm{d})$, the total SFA, the sum of 4:0 to $14: 0$, and the content of palmitic acid decreased by 7.3 , 3.7 , and $5.6 \mathrm{~g} / 100 \mathrm{~g}$ of total fatty acids, respectively, whereas the content of oleic acid (cis-9 18:1), vaccenic acid (trans-11 18:1), CLA (cis-9,trans-11 18:2), PUFA, and ALA increased by 3.0, 0.4, 0.2, 1.4, and $0.5 \mathrm{~g} / 100$ $\mathrm{g}$ of total fatty acids, respectively. When the cows ate diet C2, the content of SFA, the sum of 6:0 to 14:0, and palmitic acid decreased by $10.4,4.2$, and $9.7 \mathrm{~g} / 100 \mathrm{~g}$ of total fatty acids, respectively, whereas the content of oleic acid, vaccenic acid, CLA, PUFA, and ALA increased by $5.7,3.0,2.7,2.0$, and $0.5 \mathrm{~g} / 100 \mathrm{~g}$ of total fatty acids, respectively, compared with control diet $\mathrm{C} 0$. The improvement of the fatty acid profile that we observed with the supplementation of diet $\mathrm{C} 2$ with 1.3 $\mathrm{kg}$ of linseed is thus consistent with the fact that the milk SFA decreased linearly with increasing amounts of extruded linseed, whereas the milk MUFA, PUFA, and trans fatty acids increased linearly (Ferlay et al., 2013). Compared with the C0 diet, results suggested that de novo fatty acid synthesis was reduced in the udder of animals fed the $\mathrm{C} 2$ diet due to the feedstuffs used inducing a higher fat content and a different type of energy (higher starch and lower fiber contents).

\section{CONCLUSIONS}

The objective of this study was to evaluate the effects of the inclusion of HP and OT alone or in combination on $\mathrm{N}$ efficiency, $\mathrm{CH}_{4}$ emission, and milk production and composition in 2 experiments with dairy cows fed low$\mathrm{N}$ rations supplemented with linseed. At the economically acceptable dose we tested in these diets, hops had no significant effect on the parameters we analyzed. In contrast, supplementation of diets with OT reduced urinary $\mathrm{N}$ excretion and increased the concentration of ALA in milk. Oak tannin extracts had no significant effect on $\mathrm{CH}_{4}$ emission or on milk production. The combination of OT and HP had no more effect than OT alone except on the milk fatty acid profile, which was favorably influenced from a nutritional point of view.

\section{ACKNOWLEDGMENTS}

The authors thank the technical team of the Animal Nutrition and Sustainability Unit of the Walloon Agricultural Research Center (Gembloux, Belgium) for feeding and animal care, Eric Mignolet and Cecile Gardin (Life Sciences Institute, Université Catholique de Louvain, Belgium) for assisting in sampling and laboratory analyses, and Amélie Vanlierde of the Agricultural Product Technology Unit of the Walloon Agricultural Research Center (Gembloux, Belgium) for the methane measurements. The donation of oak tannin extracts by Oxylent (Ghislenghien, Belgium) and of hop pellets by Yakima Chief (Louvain-la-Neuve, Belgium) was much appreciated. This study was funded by the General Directorate of Agriculture of the Ministry of the Walloon Region of Belgium and by Dumoulin (Seilles, Belgium).

\section{REFERENCES}

Aguerre, M. J., M. C. Capozzolo, P. Lencioni, C. Cabral, and M. A Wattiaux. 2016. Effect of quebracho-chestnut tannin extracts at 2 dietary crude protein levels on performance, rumen fermentation, and nitrogen partitioning in dairy cows. J. Dairy Sci. 99:44764486 .

Ahnert, S., U. Dickhoefer, F. Schulz, and A. Susenbeth. 2015. Influence of ruminal Quebracho tannin extract infusion on apparent nutrient digestibility, nitrogen balance, and urinary purine derivatives excretion in heifers. Livest. Sci. 177:63-70.

Akraim, F., M. C. Nicot, P. Juaneda, and F. Enjalbert. 2007. Conjugated linolenic acid (CLnA), conjugated linoleic acid (CLA) and other biohydrogenation intermediates in plasma and milk fat of cows fed raw or extruded linseed. Animal 1:835-843.

AOAC International. 1995. Official Methods of Analysis. 16th ed. AOAC International, Arlington, VA.

Bannink, A., J. Kogut, J. Dijkstra, J. France, E. Kebreab, A. M. Van Vuuren, and S. Tamminga. 2006. Estimation of the stoichiometry of volatile fatty acid production in the rumen of lactating cows. J. Theor. Biol. 238:36-51. 
Barry, T. N., and W. C. McNabb. 1999. The implications of condensed tannins on the nutritive value of temperate forages fed to ruminants. Br. J. Nutr. 81:263-272.

Bauman, D. E., and J. M. Griinari. 2003. Nutritional regulation of milk fat synthesis. Annu. Rev. Nutr. 23:203-227.

Baumont, R., G. Tran, P. Chapoutot, G. Maxin, D. Sauvant, V. Heuzé, S. Lemosquet, and A. Lamadan. 2018. INRA feed tables used in France and temperate areas. Pages $441-548$ in INRA Feeding System for Ruminants. Wageningen Academic Publishers, Wageningen, the Netherlands.

Beauchemin, K. A., S. M. McGinn, C. Benchaar, and L. Holtshausen. 2009. Crushed sunflower, flax, or canola seeds in lactating dairy cow diets: Effects on methane production, rumen fermentation, and milk production. J. Dairy Sci. 92:2118-2127.

Beauchemin, K. A., S. M. McGinn, T. F. Martinez, and T. A. McAllister. 2007. Use of condensed tannin extract from quebracho trees to reduce methane emissions from cattle. J. Anim. Sci. 85:1990-1996.

Behr, J., and R. F. Vogel. 2009. Mechanisms of hop inhibition: Hop ionophores. J. Agric. Food Chem. 57:6074-6081.

Benchaar, C. and P. Y. Chouinard. 2009. Short communication: Assessment of the potential of cinnamaldehyde, condensed tannins, and saponins to modify milk fatty acid composition of dairy cows. J. Dairy Sci. 92:3392-3396.

Benchaar, C., F. Hassanat, R. Martineau, and R. Gervais. 2015. Linseed oil supplementation to dairy cows fed diets based on red clover silage or corn silage: Effects on methane production, rumen fermentation, nutrient digestibility, $\mathrm{N}$ balance, and milk production. J. Dairy Sci. 98:7993-8008.

Benchaar, C., T. A. McAllister, and P. Y. Chouinard. 2008. Digestion, ruminal fermentation, ciliate protozoal populations, and milk production from dairy cows fed cinnamaldehyde, quebracho condensed tannin, or Yucca schidigera saponin extracts. J. Dairy Sci. 91:4765-4777.

Benchaar, C., C. Pomar, and J. Chiquette. 2001. Evaluation of dietary strategies to reduce methane production in ruminants: A modelling approach. Can. J. Anim. Sci. 81:563-574.

Bhatta, R., U. Krishnamoorthy, and F. Mohammed. 2000. Effect of feeding tamarind (Tamarindus indica) seed husk as a source of tannin on dry matter intake, digestibility of nutrients and production performance of crossbred dairy cows in mid-lactation. Anim. Feed Sci. Technol. 83:67-74

Bhatta, R., Y. Uyeno, K. Tajima, A. Takenaka, Y. Yabumoto, I. Nonaka, O. Enishi, and M. Kurihara. 2009. Difference in the nature of tannins on in vitro ruminal methane and volatile fatty acid production and on methanogenic archaea and protozoal populations. J. Dairy Sci. 92:5512-5522.

Broderick, G. A. 2003. Effects of varying dietary protein and energy levels on the production of lactating dairy cows. J. Dairy Sci. 86:1370-1381.

Buccioni, A., M. Pauselli, C. Viti, S. Minieri, G. Pallara, V. Roscini, S. Rapaccini, M. Trabalza-Marinucci, P. Lupi, G. Conte, and M. Mele. 2015. Milk fatty acid composition, rumen microbial population, and animal performances in response to diets rich in linoleic acid supplemented with chestnut or quebracho tannins in dairy ewes. J. Dairy Sci. 98:1145-1156.

Castillo, A. R., E. Kebreab, D. E. Beever, and J. France. 2000. A review of efficiency of nitrogen utilisation in lactating dairy cows and its relationship with environmental pollution. J. Anim. Feed Sci. 9:1-32.

Chilliard, Y., F. Glasser, A. Ferlay, L. Bernard, J. Rouel, and M. Doreau. 2007. Diet, rumen biohydrogenation, cow and goat milk fat nutritional quality: A review. Eur. J. Lipid Sci. Technol. 109:828-855.

Chilliard, Y., C. Martin, J. Rouel, and M. Doreau. 2009. Milk fatty acids in dairy cows fed whole crude linseed, extruded linseed, or linseed oil, and their relationship with methane output. J. Dairy Sci. 92:5199-5211.

Christie, W. W. 1982. Lipid Analysis. 2nd ed. Pergamon Press, Oxford, UK.
Colmenero, J. J., and G. A. Broderick. 2006. Effect of dietary crude protein concentration on milk production and nitrogen utilization in lactating dairy cows. J. Dairy Sci. 89:1704-1712.

CVB. 2008. Table Booklet Feeding of Ruminants. CVB series no. 43. Centraal Veevoederbureau, Lelystad, the Netherlands.

CVB. 2016. Tabellenboek Veevoeding 2016: Voedernormen rundvee, schapen, geiten en voederwaarden voedermiddelen voor herkauwers. Accessed Sep. 15, 2017. https://www.diervoederketen.nl/index .php/cvb.

Dang Van, Q. C., L. Bejarano, E. Mignolet, D. Coulmier, E. Froidmont, Y. Larondelle, and M. Focant. 2011. Effectiveness of extruded rapeseed associated with an alfalfa protein concentrate in enhancing the bovine milk fatty acid composition. J. Dairy Sci. 94:4005-4015.

Dang Van, Q. C., C. Gardin, E. Mignolet, E. Froidmont, M. Focant, and Y. Larondelle. 2018. In vitro effects of hop pellets and oak extracts in combination on ruminal fermentation parameters. Biotechnol. Agron. Soc. Environ. 22:1-9.

Dawson, J. M., P. J. Buttery, D. Jenkins, C. D. Wood, and M. Gill. 1999. Effects of dietary quebracho tannin on nutrient utilization and tissue metabolism in sheep and rats. J. Sci. Food Agric. 79:1423-1430.

Dentinho, M. T. P., O. C. Moreira, M. S. Pereira, and R. J. B. Bessa. 2007. The use of a tannin crude extract from Cistus ladanifer L. to protect soya-bean protein from degradation in the rumen. Animal $1: 645-650$.

Dijkstra, J., O. Oenema, J. W. van Groenigen, J. W. Spek, A. M. van Vuuren, and A. Bannink. 2013. Diet effects on urine composition of cattle and $\mathrm{N}_{2} \mathrm{O}$ emissions. Animal 7(Suppl. 2):292-302

Dschaak, C. M., C. M. Williams, M. S. Holt, J.-S. Eun, A. J. Young, and B. R. Min. 2011. Effects of supplementing condensed tannin extract on intake, digestion, ruminal fermentation, and milk production of lactating dairy cows. J. Dairy Sci. 94:2508-2519.

Eckard, R. J., C. Grainger, and C. A. M. de Klein. 2010. Options for the abatement of methane and nitrous oxide from ruminant production: A review. Livest. Sci. 130:47-56.

Ferlay, A., M. Doreau, C. Martin, and Y. Chilliard. 2013. Effects of incremental amounts of extruded linseed on the milk fatty acid composition of dairy cows receiving hay or corn silage. J. Dairy Sci. 96:6577-6595.

Flythe, M. D. 2009. The antimicrobial effects of hops (Humulus lupulus L.) on ruminal hyper ammonia-producing bacteria. Lett. Appl. Microbiol. 48:712-717.

Focant, M., E. Mignolet, M. Marique, F. Clabots, T. Breyne, D. Dalemans, and Y. Larondelle. 1998. The effect of vitamin E supplementation of cow diets containing rapeseed and linseed on the prevention of milk fat oxidation. J. Dairy Sci. 81:1095-1101.

François, E., N. Thill, A. Thewis, A. Colinet, J. C. Pichon, and M. Pichon. 1978. Méthode rapide de dosage de l'oxyde de chrome dans les aliments, les fèces et les contenus digestifs par titrage après oxydation nitro-perchlorique. Ann. Zootech. 27:355-361.

Frank, B., M. Persson, and G. Gustafsson. 2002. Feeding dairy cows for decreased ammonia emission. Livest. Sci. 76:171-179.

Frutos, P., G. Hervas, F. J. Giraldez, M. Fernandez, and A. R. Mantecon. 2000. Digestive utilization of quebracho-treated soya bean meal in sheep. J. Agric. Sci. 134:101-108.

Frutos, P., G. Hervás, F. J. Giráldez, and A. R. Mantecón. 2004 Review. Tannins and ruminant nutrition. Span. J. Agric. Res. 2:191-202.

Gerber, P. J., H. Steinfeld, B. Henderson, A. Mottet, C. Opio, J. Dijkman, A. Falcucci, and G. Tempio. 2013. Tackling climate change through livestock - A global assessment of emissions and mitigation opportunities. Accessed Jul. 26, 2018. http://www.fao.org/ docrep/018/i3437e/i3437e.pdf.

Glasser, F., A. Ferlay, and Y. Chilliard. 2008. Oilseed lipid supplements and fatty acid composition of cow milk: A meta-analysis. J. Dairy Sci. 91:4687-4703.

Goel, G., and H. P. S. Makkar. 2012. Methane mitigation from ruminants using tannins and saponins. Trop. Anim. Health Prod. 44:729-739. 
Gonthier, C., A. F. Mustafa, R. Berthiaume, H. V. Petit, R. Martineau, and D. R. Ouellet. 2004. Effects of feeding micronized and extruded flaxseed on ruminal fermentation and nutrient utilization by dairy cows. J. Dairy Sci. 87:1854-1863.

Gonthier, C., A. F. Mustafa, D. R. Ouellet, P. Y. Chouinard, R. Berthiaume, and H. V. Petit. 2005. Feeding micronized and extruded flaxseed to dairy cows: Effects on blood parameters and milk fatty acid composition. J. Dairy Sci. 88:748-756.

Grainger, C., T. Clarke, M. J. Auldist, K. A. Beauchemin, S. M. McGinn, G. C. Waghorn, and R. J. Eckard. 2009. Potential use of Acacia mearnsii condensed tannins to reduce methane emissions and nitrogen excretion from grazing dairy cows. Can. J. Anim. Sci. 89:241-251.

Griffiths, W. M., C. E. F. Clark, D. A. Clark, and G. C. Waghorn 2013. Supplementing lactating dairy cows fed high-quality pasture with black wattle (Acacia mearnsii) tannin. Animal 7:1789-1795.

Hara, A., and N. S. Radin. 1978. Lipid extraction of tissues with a low-toxicity solvent. Anal. Biochem. 90:420-426.

Hassanat, F., R. Gervais, C. Julien, P. Y. Chouinard, D. I. Masse, A. Lettat, H. V. Petit, and C. Benchaar. 2013. Replacing alfalfa silage with corn silage in dairy cow diets: Effects on enteric methane production, ruminal fermentation, digestion, $\mathrm{N}$ balance, and milk production. J. Dairy Sci. 96:4553-4567.

Hatew, B., S. C. Podesta, H. Van Laar, W. F. Pellikaan, J. L. Ellis, J. Dijkstra, and A. Bannink. 2015. Effects of dietary starch content and rate of fermentation on methane production in lactating dairy cows. J. Dairy Sci. 98:486-499.

Henke, A., E. Westreicher-Kristen, J. Molkentin, U. Dickhoefer, K. Knappstein, M. Hasler, and A. Susenbeth. 2017. Effect of dietary quebracho tannin extract on milk fatty acid composition in cows. J. Dairy Sci. 100:6229-6238.

Hurtaud, C., F. Faucon, S. Couvreur, and J.-L. Peyraud. 2010. Linear relationship between increasing amounts of extruded linseed in dairy cow diet and milk fatty acid composition and butter properties. J. Dairy Sci. 93:1429-1443

Jayanegara, A., F. Leiber, and M. Kreuzer. 2012. Meta-analysis of the relationship between dietary tannin level and methane formation in ruminants from in vivo and in vitro experiments. J. Anim. Physiol. Anim. Nutr. (Berl.) 96:365-375.

Johnson, K., M. Huyler, H. Westberg, B. Lamb, and P. Zimmerman. 1994. Measurement of methane emissions from ruminant livestock using a SF6 tracer technique. Environ. Sci. Technol. 28:359-362.

Kronberg, S. L., E. J. Scholljegerdes, G. Barcelo-Coblijn, and E. J Murphy. 2007. Flaxseed treatments to reduce biohydrogenation of alpha-linolenic acid by rumen microbes in cattle. Lipids 42:11051111.

Lavrenčič, A., A. Levart, I. J. Košir, and A. Čerenak. 2014. Influence of two hop (Humulus lupulus L.) varieties on in vitro dry matter and crude protein degradability and digestibility in ruminants. J. Sci. Food Agric. 94:1248-1252.

Lavrenčič, A., A. Levart, I. J. Kosir, and A. Cerenak. 2015. In vitro gas production kinetics and short-chain fatty acid production from rumen incubation of diets supplemented with hop cones (Humulus lupulus L.). Animal 9:576-581.

Leduc, M., M.-P. Létourneau-Montminy, R. Gervais, and P. Y. Chouinard. 2017. Effect of dietary flax seed and oil on milk yield, gross composition, and fatty acid profile in dairy cows: A meta-analysis and meta-regression. J. Dairy Sci. 100:8906-8927.

Leonardi, C., M. Stevenson, and L. E. Armentano. 2003. Effect of two levels of crude protein and methionine supplementation on performance of dairy cows. J. Dairy Sci. 86:4033-4042.

Martin, C., A. Ferlay, P. Mosoni, Y. Rochette, Y. Chilliard, and M. Doreau. 2016. Increasing linseed supply in dairy cow diets based on hay or corn silage: Effect on enteric methane emission, rumen microbial fermentation, and digestion. J. Dairy Sci. 99:3445-3456.

Martin, C., D. Morgavi, M. Doreau, and J. P. Jouany. 2006. Comment réduire la production de méthane chez les ruminants? Fourrages (Versailles) 187:283-300.

Martin, C., D. P. Morgavi, and M. Doreau. 2010. Methane mitigation in ruminants: From microbe to the farm scale. Animal 4:351-365.
Martin, C., J. Rouel, J. P. Jouany, M. Doreau, and Y. Chilliard. 2008 Methane output and diet digestibility in response to feeding dairy cow crude linseed, extruded linseed or linseed oil. J. Anim. Sci. $86: 2642-2650$.

Martineau, R., H. V. Petit, C. Benchaar, H. Lapierre, D. R. Ouellet, D. Pellerin, and R. Berthiaume. 2008. Effects of lasalocid or monensin on in situ biohydrogenation of flaxseed and sunflower seed unsaturated fatty acids. Can. J. Anim. Sci. 88:335-339.

McNabb, W. C., J. S. Peters, L. Y. Foo, G. C. Waghorn, and S. J Jackson. 1998. Effect of condensed tannins prepared from several forages on the in vitro precipitation of ribulose-1,5-bisphospathe carboxilase (rubisco) protein and its digestion by trypsin (EC 2.4.21.4) and chymotrypsin (EC 2.4.21.1). J. Sci. Food Agric. $77: 201-212$

Meignan, T., C. Lechartier, G. Chesneau, and N. Bareille. 2017. Effects of feeding extruded linseed on production performance and milk fatty acid profile in dairy cows: A meta-analysis. J. Dairy Sci. 100:4394-4408.

Min, B. R., T. N. Barry, G. T. Attwood, and W. C. McNabb. 2003. The effect of condensed tannins on the nutrition and health of ruminants fed fresh temperate forages: A review. Anim. Feed Sci. Technol. 106:3-19.

Mohammed, R., S. M. McGinn, and K. A. Beauchemin. 2011. Prediction of enteric methane output from milk fatty acid concentrations and rumen fermentation parameters in dairy cows fed sunflower, flax, or canola seeds. J. Dairy Sci. 94:6057-6068.

Mojtahedi, M., and M. D. Mesgaran. 2011. Effects of the inclusion of dried molassed sugar beet pulp in a low-forage diet on the digestive process and blood biochemical parameters of Holstein steers. Livest. Sci. 141:95-103.

Mueller-Harvey, I. 2006. Unravelling the conundrum of tannins in animal nutrition and health. J. Sci. Food Agric. 86:2010-2037.

Münnich, M., R. Khiaosa-ard, F. Klevenhusen, A. Hilpold, A. KholParisini, and Q. Zebeli. 2017. A meta-analysis of feeding sugar beet pulp in dairy cows: Effects on feed intake, ruminal fermentation, performance, and net food production. Anim. Feed Sci Technol. 224:78-89.

Mutsvangwa, T., K. L. Davies, J. J. McKinnon, and D. A. Christensen. 2016. Effects of dietary crude protein and rumen-degradable protein concentrations on urea recycling, nitrogen balance, omasal nutrient flow, and milk production in dairy cows. J. Dairy Sci. 99:6298-6310.

Narvaez, N., Y. Wang, Z. Xu, T. Alexander, S. Garden, and T. McAllister. 2013. Effects of hop varieties on ruminal fermentation and bacterial community in an artificial rumen (rusitec). J. Sci. Food Agric. 93:45-52.

Narvaez, N., Y. Wang, Z. Xu, and T. McAllister. 2011. Effects of hops on in vitro ruminal fermentation of diets varying in forage content. Livest. Sci. 138:193-201.

Odongo, N. E., M. M. Or-Rashid, R. Bagg, G. Vessie, P. Dick, E. Kebreab, J. France, and B. W. McBride. 2007. Long-term effects of feeding monensin on milk fatty acid composition in lactating dairy cows. J. Dairy Sci. 90:5126-5133.

Patra, A. K., and J. Saxena. 2011. Exploitation of dietary tannins to improve rumen metabolism and ruminant nutrition. J. Sci. Food Agric. 91:24-37.

Petit, H. V., M. Ivan, and P. S. Mir. 2005. Effects of flaxseed on protein requirements and $\mathrm{N}$ excretion of dairy cows fed diets with two protein concentrations. J. Dairy Sci. 88:1755-1764.

Sakamoto, K., and W. Konings. 2003. Beer spoilage bacteria and hop resistance. Int. J. Food Microbiol. 89:105-124.

Sauer, F. D., V. Fellner, R. Kinsman, J. K. Kramer, H. A. Jackson, A. J. Lee, and S. Chen. 1998. Methane output and lactation response in Holstein cattle with monensin or unsaturated fat added to the diet. J. Anim. Sci. 76:906-914.

Silanikove, N., Z. Nitsan, and A. Perevolotsky. 1994. Effect of a daily supplementation of polyethylene glycol on intake and digestion of tannin-containing leaves (Ceratonia siliqua) by sheep. J. Agric. Food Chem. 42:2844-2847. 
Silanikove, N., A. Perevolotsky, and F. D. Provenza. 2001. Use of tannin-binding chemicals to assay for tannins and their negative postingestive effects in ruminants. Anim. Feed Sci. Technol. 91:69-81.

Simpson, W. J. 1993. Studies on the sensitivity of lactic acid bacteria to hop bitter acids. J. Inst. Brew. 99:405-411.

Staerfl, S. M., S. L. Amelchanka, T. Kälber, C. R. Soliva, M. Kreuzer, and J. O. Zeitz. 2012. Effect of feeding dried high-sugar ryegrass (AberMagic) on methane and urinary nitrogen emissions of primiparous cows. Livest. Sci. 150:293-301.

Ulyatt, M. J., J. C. Mc Rae, R. T. J. Clarke, and P. D. Pearce. 1975. Quantitative digestion of fresh herbage by sheep: IV. Protein synthesis in the stomach. J. Agric. Sci. 84:453-458.

van Duinkerken, G., M. C. Blok, A. Bannink, J. W. Cone, J. Dijkstra, A. M. Van Vuuren, and S. Tamminga. 2011. Update of the Dutch protein evaluation system for ruminants: The DVE/OEB 2010 system. J. Agric. Sci. 149:351-367.

Van Es, A. J. H. 1975. Feed evaluation for dairy cows. Livest. Prod. Sci. 2:95-107.
Van Nevel, C., and D. I. Demeyer. 1995. Lipolysis and biohydrogenation of soybean oil in the rumen in vitro: Inhibition by antimicrobials. J. Dairy Sci. 78:2797-2806.

Vanlierde, A., M. L. Vanrobays, N. Gengler, P. Dardenne, E. Froidmont, H. Soyeurt, S. Mc Arland, E. Lewis, M. Deighton, M. Mathot, and F. Dehareng. 2016. Milk mid-infrared spectra enable prediction of lactation-stage dependent methane emissions of dairy cattle within routine population-scale milk recording schemes. Anim. Prod. Sci. 56:258-264.

Waghorn, G. C., M. H. Tavendale, and D. R. Woodfield. 2002. Methanogenesis in forages fed to sheep. Proc. New Zealand Grassl. Assoc. $64: 167-171$

Wu, Z., and J. T. Huber. 1994. Relationship between dietary fat supplementation and milk protein concentration in lactating cows: A review. Livest. Prod. Sci. 39:141-155.

Zhou, Y. Y., H. L. Mao, F. Jiang, J. K. Wang, J. X. Liu, and C. S. Mc-Sweeney. 2011. Inhibition of rumen methanogenesis by tea saponins with reference to fermentation pattern and microbial communities in Hu sheep. Anim. Feed Sci. Technol. 166-167:93-100. 